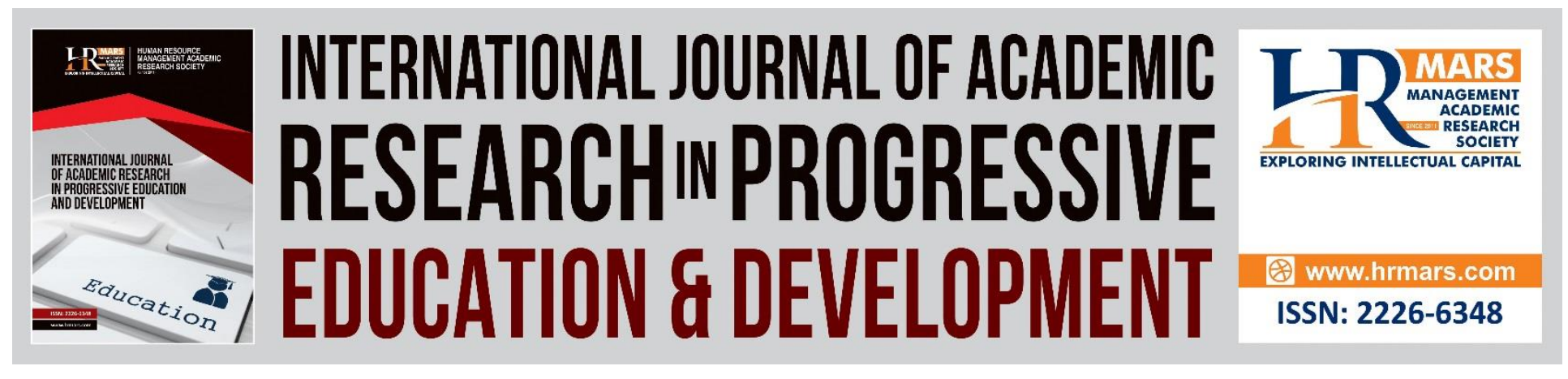

\title{
Relationship between Teacher Training Practices and Transition to Secondary School for Public Primary School Learners with Disabilities in Meru County, Kenya
}

Joshua Mburugu M'mbijiwe, Nelson Jagero, Beatrice M. Mburugu Hillary K. Barchok

To Link this Article: http://dx.doi.org/10.6007/IJARPED/v7-i2/4133

DOI: $10.6007 /$ IJARPED/v7-i2/4133

Received: 12 March 2018, Revised: 03 April 2018, Accepted: 19 April 2018

Published Online: 22 April 2018

In-Text Citation: (M'mbijiwe, Jagero, Mburugu, \& Barchok, 2018)

To Cite this Article: M’mbijiwe, J. M., Jagero, N., Mburugu, B. M., \& Barchok, H. K. (2018). Relationship between Teacher Training Practices and Transition to Secondary School for Public Primary School Learners with Disabilities in Meru County, Kenya. International Journal of Academic Research in Progressive Education and Development, 7(2), 64-71.

Copyright: (C) 2018 The Author(s)

Published by Human Resource Management Academic Research Society (www.hrmars.com)

This article is published under the Creative Commons Attribution (CC BY 4.0) license. Anyone may reproduce, distribute, translate and create derivative works of this article (for both commercial and non-commercial purposes), subject to full attribution to the original publication and authors. The full terms of this license may be seen at: http://creativecommons.org/licences/by/4.0/legalcode

Vol. 7, No. 2, April 2018, Pg. 64 - 71

http://hrmars.com/index.php/pages/detail/IJARPED

JOURNAL HOMEPAGE

Full Terms \& Conditions of access and use can be found at http://hrmars.com/index.php/pages/detail/publication-ethics 


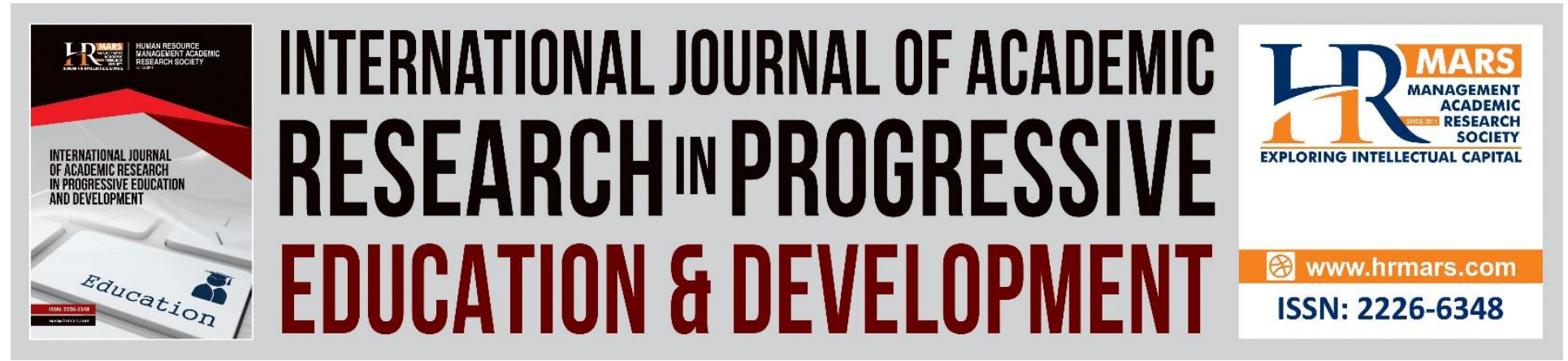

\title{
Relationship between Teacher Training Practices and Transition to Secondary School for Public Primary School Learners with Disabilities in Meru County, Kenya
}

\author{
Joshua Mburugu M'mbijiwe \\ Meru, Kenya. \\ Email: Mburugu.joshua@gmail.com \\ Prof. Nelson Jagero \\ Department of Education Chuka University, \\ Chuka, Kenya \\ Email: jageronelson@yahoo.com \\ Dr. Beatrice M. Mburugu \\ Department of Education Chuka University, \\ Chuka, Kenya \\ Email: bmburugu@yahoo.com \\ Dr. Hillary K. Barchok \\ Faculty of Education Chuka University, Chuka, Kenya \\ Email: barchokhillary@yahoo.com
}

\begin{abstract}
Access to quality education and transition from primary to secondary school has been low for learners with disabilities compared to non-disabled learners over the years in Kenya. The Kenya Government has established several strategic initiatives and mobilized required resources to address this challenge. Among the key strategies is introduction of special needs education policy in the year 2009 in which enhancement of special needs education teacher training is a major ingredient. Despite the Government interventions, transition of learners with disabilities has remained below $30 \%$ nationally and below $16 \%$ in Meru County over ten years compared to transition for non-disabled learners that has been on a continuous increase to above $92 \%$. This study sought to determine the relationship between practices of special needs education
\end{abstract}


DEVELOPMENT

Vol. 7, No. 2, April 2018, E-ISSN: 2226-6348 @ 2018 HRMARS

teachers training and transition of learners with disabilities. The research employed correlation research design and a sample of 350 respondents to represent a study population of 3720 subjects. Data obtained in the study was analyzed using inferential statistics such as analysis of variance and linear regression with the aid of a statistical package for social sciences (SPSS) version 21. Findings of the study revealed that practice of teacher training has significant impact on transition of public primary school learners with disabilities to secondary school. According to the findings, every $10 \%$ improvement in special needs education teacher training practice would raise transition to secondary school for learners with disabilities by $5.14 \%$. Based on the findings, the study recommends that the Ministry of education should establish and facilitate a programme for regular in-service training of special needs education teachers to keep them abreast with the most effective and modern approaches to teach learners with disabilities. The Kenya Institute of Curriculum Development should establish a curriculum that is adaptable to the disabled learners which will enable teachers to effectively plan teaching-learning activities and address learning needs of every disabled learner.

Keywords: Learners with disabilities, Transition, Teacher Training, Public Primary School.

\section{Introduction}

The global push on education for all (EFA) as a measure for national development and individual's ability to effectively function in the society motivates everyone to put effort in attaining the highest possible education in pursuit of the expected benefits (United Nations Educational, Scientific and Cultural Organization,2005). It is expected that educated people including those from marginalized groups are not only able to achieve independence but also participate and function better in various aspects of life (Muganda \& Mwangi, 2002). For persons with disabilities, attaining not only quality education but numerous other opportunities for their successful living is difficult due to a host of problems. Majority of them live in hostile and poor conditions where their security is compromised. They are marginalized, discriminated and have no opportunity to develop themselves, instead they remain voiceless and their rights are jeopardized due to social prejudices (World Health Organization, 2011).

The Government of Kenya has established several commissions and policies in the effort to address issues on provision of quality education to all including the 4.44 million disabled citizenry. These commissions include the Kamunge Report (1988) a Presidential Working Paper on education and training for the next decade and above; Totally Integrated Quality Education and Training (TIQET-Koech Report, 1999); the Ko'chung Report of 2003 on Special Needs Education Appraisal Exercise; the persons with disabilities Act (2003) and the Ministry of Education Strategic Plan (ROK, 2009) on the aims of SNE to empower disabled persons to realize their full potential. Quite a number of recommendations from these reports have been implemented with a common focus on education access, retention, quality, equity and relevance of education being offered. Most recent of the policy initiatives is the national SNE policy framework (ROK, 2009) that comprehensively reflects the Government's commitment to provision of special needs education. It is expected that implementation of these policies will lead to universal education and training for all learners including those with special education needs (Ojiambo, 2009).

Among the key provisions of SNE policy is quality teacher training and development. With consideration of Kenya's education system being examination oriented since independence, productivity of teachers in the teaching process has been viewed as a correlation between the 
Vol. 7, No. 2, April 2018, E-ISSN: 2226-6348 @ 2018 HRMARS

quality of training given to teachers and achievement of learners in examinations. This means that good learners' academic achievement is associated to effective teaching (GOK, 2009). The Government therefore ensures not only resource mobilization but also emphasis on improved teacher training with specific reference to acquisition of knowledge, skills and right attitudes to enable them influence learners outcomes and transition directly (Clifford, Maxwell \& Field, 2006). While education access and transition from primary to secondary school has been on an upward trend, transition among learners with disabilities (LWDs) remains low in Kenya. Estimates by the Ministry of Education (2016) indicate that transition rate for LWDs has remained less than $30 \%$ compared to $84.0 \%$ for learners without disabilities in Kenya over the years. In Meru County, the rate has remained lower than $\mathbf{1 6 . 0 \%}$ for ten years. These disparities in transition rates exist despite increased resources and policy mitigations geared to address the gap. This study therefore sought to bridge this gap by determining the relationship between SNE teacher training practices and transition to secondary school for learners with disabilities in Meru County, Kenya.

\section{Literature Review}

Training of teachers is intended to equip teachers with skills and knowledge to enable them effectively influence learner achievement. As outlined in the provisions of SNE policy framework (2009), Kenya has well-structured teacher training programmes to achieve this purpose.

Several studies have shown that teacher training affect content delivery in the classroom which in turn influence learners' outcomes and transition. Gamoran (2006) in University of Wisconsin noted that training enhances content masterly and delivery in classroom resulting in improved learner outcome. Teachers who are well trained are able to incorporate different teaching approaches hence influencing learner outcomes positively (Welsh 2010 and Gursky, 2003). A study by National Staff Development Council (2003) revealed that effective teacher training enhances ideologies and instructional techniques which empower teachers to deliver content to learners better. This concurs with finding of a study by Jackson and Davis (2000) that well trained teachers demonstrate knowledge and skills in content delivery that lead to enhanced learner outcomes. A study by the Programme for International Students Assessment (PISA, 2006) on teachers' competence in handling inclusive classes in Finland revealed good academic performance and transition from one level to another for LWDs as a product of effective teacher training on teaching pedagogical approaches.

Studies have also shown that countries where teachers were inadequately trained, learners with disabilities performed poorly followed by low rates of transition to higher levels of education. Casely-Hayford, Thomas, Teteh, Adams and Imranah (2011) carried out study on policy practices on inclusive education in northern Ghana. The study revealed inadequate teacher training which was reflected to poor learner performance and transition to higher education. Mwangi (2013) in his study on exploring Government policy and teachers' understanding in Kenyan public primary schools revealed that teachers handling SNE learners lacked competence on strategies to address barriers to effective learning of LWDs. Consequently, learners' achievements were compromised. The reviewed literature looked at effective teacher training to develop knowledge and skills expected to positively influence examination outcome and transition from one level of education to another for learners with disabilities. Practices of the acquired teaching skills in the classroom 
INTERNATIONAL JOURNAL OF ACADEMIC RESEARCH IN PROGRESSIVE EDUCATION AND DEVELOPMENT

Vol. 7, No. 2, April 2018, E-ISSN: 2226-6348 @ 2018 HRMARS

and how this influences outcomes and transition of LWDs has not been studied. This study therefore sought to address this gap.

\section{Methodology}

The study employed a correlation research design. The population of study was 3720 subjects and a sample of 350 respondents selected by simple random sampling for learners with disabilities and purposive sampling for teachers and EARC officers. Primary data was collected using questionnaires for learners, teachers and interview schedule for EARC officers. The researcher used observation checklist to guide him in observing practices of teacher training in SNE classrooms.

\section{Data Analysis}

After all data was collected, cleaning and editing of quantitative data was done, coded and fed into a computer programme for analysis using inferential statistics which include analysis of variance and linear regression. A Statistical Package for Social Sciences (SPSS) computer programme version 21 was used to aid analysis. Martin \& Acuna (2002) notes that SPSS is able to handle large amounts of data; it is time saving and also quite efficient. Frequency tables were used to present analysed quantitative data.

\section{Results and Discussions}

To determine the impact of teacher training practices on transition of public primary school LWDs to secondary school the researcher regressed data on transition with data on teacher training practices as shown in the table below.

Regression Model for Teacher Training on Transition of LWDs

\begin{tabular}{lcccc}
\hline Model & $\mathrm{R}$ & R Square & Adjusted R Square & $\begin{array}{c}\text { Std. Error of the } \\
\text { Estimate }\end{array}$ \\
\hline 1 & $.275^{\mathrm{a}}$ & .076 & .073 & 1.10551 \\
\hline
\end{tabular}

Predictors: (Constant), teacher training practices

The results showed that analysis of quantitative data from all questionnaires and observation checklists gave R-Square $=0.076$. This implied that teacher training practices had a significant impact of $7.6 \%$ on transition of LWDs to secondary school.

The researcher sought to confirm further the significance of teacher training practices on transition of LWDs by determining analysis of variance (ANOVA) on the study data. The results are presented in the table below.

Analysis of variance on Teacher Training practices and Transition of LWDs

\begin{tabular}{lccccc}
\hline \hline Model & Sum of Squares & Df & Mean Square & F & Sig. \\
\hline Regression & 29.574 & 1 & 29.574 & 24.198 & $.010^{b}$ \\
Residual & 360.538 & 295 & 1.222 & & \\
Total & 390.112 & 296 & & & \\
\hline
\end{tabular}

Dependent Variable: Transition

Predictors: (Constant), Teacher Training practices 
DEVELOPMENT

Vol. 7, No. 2, April 2018, E-ISSN: 2226-6348 @ 2018 HRMARS

The findings revealed that significance of teacher training practices was $0.010<0.05$ at a significance threshold of $\alpha=0.05$. This implied that teacher training practices was highly significant in effecting transition of LWDs. The fairly big F value (24.198) further supports the finding that teacher training practices had significant impact on transition of LWDs.

The researcher sought to estimate the quantitative impact of teacher training practices on transition of LWDs. He therefore regressed the two study variables (teacher training and transition) as presented in the table below.

Regression Coefficient for Teacher Training and Transition of LWDs

\begin{tabular}{|c|c|c|c|c|c|}
\hline \multirow[t]{2}{*}{ Model } & \multicolumn{2}{|c|}{ Unstandardized Coefficients } & \multirow{2}{*}{$\begin{array}{c}\text { Standardized } \\
\text { Coefficients } \\
\text { Beta } \\
\end{array}$} & \multirow[b]{2}{*}{$\mathrm{t}$} & \multirow[b]{2}{*}{ Sig.(P) } \\
\hline & $\mathrm{B}$ & Std. Error & & & \\
\hline (Constant) & .828 & .363 & & 2.282 & .023 \\
\hline $\begin{array}{l}\text { Teacher training } \\
\text { practices }\end{array}$ & .514 & .105 & .275 & 4.919 & .020 \\
\hline
\end{tabular}

Dependent Variable: transition

The results revealed that $\mathrm{P}=0.020, \mathrm{P}<0.05$ and $\mathrm{t}=4.919, \mathrm{t}>2.00$ at a significance level of $\alpha=0.05$ and $t=2.00$. This reflects a big significant impact of teacher training practices on transition of LWDs. The regression coefficient value (composite value $B$ ) of teacher training was 0.514 which means that $1 \%$ improvement in teacher training practices would increase transition of LWDs by $0.514 \%$ in public primary schools of Meru County. The Linear Regression equation to quantitatively estimate the level of transition was stated as follows:

Where $\quad \begin{aligned} & \mathrm{T}=0.514 \mathrm{tt}+0.828 \\ & \mathrm{~T}=\text { Transition }\end{aligned}$
$\mathrm{tt}=$ Teacher Training practices
$0.828=$ Constant
$0.514=$ Estimate of expected increase in transition of LWDs to secondary school
upon improvement in teacher training practices.

From this equation, it was concluded that for every $10 \%$ improvement in teacher training practices, transition of LWDs would increase by $5.14 \%$.

From the findings, teachers were given adequate pre-service training but their proficiency was affected by lack of regular in-service training on current teaching approaches. These finding do not concur with findings of a study by Programme for International Students Assessment (PISA, 2006) conducted in Finland to investigate teacher competence in handling inclusive education of challenged learners. Findings of the study revealed high level of teachers' proficiency in planning and implementation of teaching programmes. The education ministry allowed teachers to flexibly plan learning programmes according to the learners' specific needs which led to high learner outcomes. The difference in learners' achievements in the two countries indicates that Kenya's special needs education programme should be structured in a manner that allows teachers to flexibly plan teaching/learning process to accommodate special disability limitations and needs of learners to enhance efficiency and effectiveness in the process. 
Findings from analysis of data from observation checklist revealed that the curriculum and learning programme applied on learners with disabilities in Kenya was unsuitable to LWDs because it was meant for learners without disabilities therefore does not accommodate disability limitations. In addition, timing of lessons among other aspects of the programme interfered with implementation of planned lesson content by SNE teachers hence compromising learner outcomes. These findings concur with those of a study conducted in Zambia to inquire on the kind of curriculum used for SNE and the challenges faced in implementing the curriculum (Ojara, 2004). Findings of the study showed that the curriculum was not adapted to accommodate disability limitations of learners. In addition, the programme was inclined to theoretical pedagogy instead of practical approach. This negatively affected outcomes of the learners regardless of teaching skills demonstrated by SNE teachers in Zambia. Findings of study by Ojara (2004) is beneficial to the current study in that application of practical approaches other than theoretical pedagogy in SNE if implemented in Kenya would be effective in influencing learner achievements.

\section{Conclusions}

From the findings of this study, a number of conclusions were drawn: teachers were well equipped with adequate content masterly during pre-service training to enable them teach SNE classes effectively. However, in-service training was inadequate though very critical to continuously enrich teachers with most modern and effective teaching approaches. Effective application of training skills was impended by the teaching/learning programme that was meant for learners without disabilities. Aspects like lesson timing among others was too inadequate because LWDs require extra time to ensure every learner-teacher contact to address each learner's needs. Learners with disabilities require skills based practical teaching approach for effective learning. This was not possible due to resource limitation in schools offering special education. Teachers therefore resulted to theoretical pedagogy that has little benefit to LWDs. Teachers were expected to strictly adhere to the regular school programme because evaluation on SNE teachers and learners is done on the same standards as teachers and learners in the regular schools. In consideration that learners with disabilities require longer time to handle learning tasks with teacher's support than peers without disabilities, short lesson time reduces teacher-learner contact. Consequently, LWDs either do not complete the tasks or they are not able to start which directly lower learner achievements.

\section{Recommendations}

Based on the findings and conclusions of this study, it is recommended that the Ministry of Education should establish and facilitate a programme for regular in-service training of SNE teachers. By this, teachers will be kept abreast with the most effective and modern approaches to teach LWDs. This will benefit the learners because practices of teacher training skill in SNE classrooms will be improved resulting in improved learner outcomes and transition to higher education levels. It was also recommended that the Ministry of education through the Kenya Institute for Curriculum Development (KICD) should establish an adaptable curriculum and learning programme that is suitable for LWDs. Allowing enough time coupled with provision of enough learning resources would ensure effective learner-teacher contact followed by improved 
INTERNATIONAL JOURNAL OF ACADEMIC RESEARCH IN PROGRESSIVE EDUCATION AND DEVELOPMENT

Vol. 7, No. 2, April 2018, E-ISSN: 2226-6348 @ 2018 HRMARS

performance and transition of learners. Availability of learning resources and improved content delivery by teachers will motivate learners to work harder leading to higher performance and transition. With improved learner achievements, teachers will not only be motivated but they will feel actualized and experience job satisfaction.

\section{CORRESPONDING AUTHOR}

JOSHUA MBURUGU M'MBIJIWE

Email: Mburugu.joshua@gmail.com

PO BOX 111-60200

MERU, KENYA.

\section{References}

Casely-Hayford, L., Thomas, Q., Tetteh, P., Adams, R. \& Imranah, A. (2011). Inclusive Education in Ganah: A look at Policy and Practice in Northern Ganah. Accra: Voluntary Services Organization (VSO).

Clifford, R., Maxwell, K \& Field, C (2006). Towards Better Definition and Measurement of Early Childhood Professional Development. Baltimore: Brooks Publishing.

Gamoran, A. (2006). Strong Professional Community Benefits Teachers and Students. Madison: University of Wisconsin Press

Gursky, T. \& Clifford, R. (2000). Evaluating Professional Development. Thousand Oaks CA: Corwin Press.

Martin, K. \& Acuna, C. (2002). SPSS for Institutional Research. Bucknell Lewisburg, Pensylvania: University Press. 49.

Ministry of Education. (2016). Education Statistical Booklet, Nairobi: Government Printers

Muganda, K. C. (2002). Gender Equity in Education and Learners at Risk: The Role of Distance and Open Learning. A Peper Presented to the $8^{\text {th }}$ International Interdisciplinary Congress on Women's World 2002, Makerere University, Kampala-Uganda.

Mwangi, L. (2013). Special Needs Education in Kenya Primary Schools: Exploring Government Policy and Teachers' Understanding. London: Brunel University.

Ojara, P. (2004). Aims of Education and Curriculum Planning in Special Education Units and Schools in Lusaka, Zambia: A Qualitative Study of Special Education Teachers' Views and Classroom Practice. Lusaka: University of Jyvaskyla. Unpublished PhD Thesis.

Ojiambo, P. O. (2009). Quality of Education and its Role in National Development: A Case Study of Kenya's Educational Reforms. Kenya Studies Review: 1(1), 133-

Programme for International Students Assessment. (2006). Youth in Transition Survey in Canada. Ontario: PISSA.

Republic of Kenya. (2009), Kenya Demographic and Health Survey http:// dhsporogram.com/pubs/pdf/fr229.pdf

UNESCO. (2005). Education for All: The Quality Imperative. EFA Global Monitoring Report 2005; Paris: UNESCO.

WHO. (2011). World Report on Disability. Geneva, Switzerland, World Health Organization. 